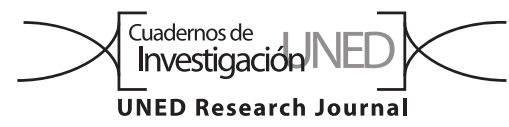

\title{
Halochromic properties and antimicrobial potential of crude extracts from five species of ornamental plants
}

\author{
Michael O. Kusimo ${ }^{1 *}$, Henry Ukoha ${ }^{2}$, Aderonke Oludare ${ }^{3}$, Oluwatoyin Afolabi ${ }^{3,4}$ \& Matthew Agwae ${ }^{5}$ \\ 1. Centre for Research in Infectious Diseases (CRID), LSTM Research Unit, P.O. Box 13591, Yaoundé, Cameroon; gkusimo@gmail.com, \\ (D) https://orcid.org/0000-0002-0447-0398 \\ 2. Universite Africaine De Technologie et de Management, Benin Republic; henryg6pd@gmail.com, \\ (D) https://orcid.org/0000-0003-0798-8843 \\ 3. Africa Rice Center, 01 BP 2031, Cotonou, Bénin; ronkelola123@gmail.com, \\ (iD) https://orcid.org/0000-0001-8657-7166 \\ 4. University of Ghent, Phytopathology Laboratory, Belgium; samtoyin@gmail.com, \\ (D) https://orcid.org/0000-0001-7363-2576 \\ 5. University of Liverpool, North West Cancer Research Centre, 200 London Road, Liverpool L3 9TA, United Kingdom; agwaeme@yahoo.co.uk, \\ (D) https://orcid.org/0000-0003-2877-1483
}

\author{
Received 14-I-2019 • Corrected 12-III-2019 • Accepted 03-IV-2019
}

DOI: https://doi.org/10.22458/urj.v11i3.2586

\begin{abstract}
Introduction: the colours of flowers are a result of secondary metabolites that have long been used in the medical and textile industries, and those that are halochromic are used in colour display because they change color according to $\mathrm{pH}$ changes, but many species are yet to be studied in detail. Objective: to explore the halochromic properties and the antimicrobial potentials of the crude extracts of several ornamental plants. Methods: we used aqueous and organic solvents to extract pigments from petals of five fascinating flowers planted around International Institute of Tropical Agriculture station, Cotonou, Benin: Allamanda blanchetii, Cascabela thevetia, Eichhornia crassipes, Ixora casei and Thunbergia erecta, followed by an investigation into their halochromic properties. Antibacterial potentials of the extracts were tested on important rice pathogens: Xanthomonas oryzae pv. oryzae, and Pantoea agglomerans, which are gram-negative bacteria; and on Bacillus subtilis, a gram-positive bacterium. Results: The crude extracts of $T$. erecta and A. blanchetii have good halochromic properties within $\mathrm{pH} 2-12$, exhibiting distinct colours. The chromophores of the C. thevetia, E. crassipes, and I. casei are not halochromic as the colours of the crude extracts remain the same at the $\mathrm{pH}$ range except $\mathrm{pH} 12$ which is similar for the five extracts. Crude extracts of $T$. erecta inhibited growth of $P$. agglomerans without development of resistance, whereas the bacteria developed resistance against Penicillin after $18 \mathrm{hrs}$ of incubation. T. erecta and A. blanchetii were able to inhibit growth of $X$. oryzae and both inhibited $B$. subtilis. Conclusion: Pigments from both $T$. erecta and $A$. blanchetii are good $\mathrm{pH}$ indicators; however, $T$. erecta is a better antibacterial agent than $A$. blanchetii because it has broad-spectrum activities against bacteria.
\end{abstract}

Key words: antimicrobial, halochromism, Thunbergia erecta, anthocyanin, Xanthomonas oryzae pv. Oryzae, Pantoea agglomerans, Bacillus subtilis.
RESUMEN: "Propiedades halocrómicas y potenciales antimicrobianos de extractos crudos de cinco plantas ornamentales". Introducción: los colores de las flores son el resultado de metabolitos secundarios, que se han utilizado durante mucho tiempo en las industrias médica y textil, y los que son halocrómicos se usan en la visualización a color porque cambian de color según los cambios de $\mathrm{pH}$, pero muchas especies aún no se han estudiado en detalle. Objetivo: explorar las propiedades halocrómicas y los potenciales antimicrobianos de los extractos crudos de plantas ornamentales. Métodos: utilizamos disolventes acuosos y orgánicos para extraer pigmentos de pétalos de cinco flores fascinantes plantadas alrededor de la Estación Internacional de Agricultura Tropical, Cotonou, Benin: Allamanda blanchetii, Cascabela thevetia, Eichhornia crassipes, Ixora casei y Thunbergia erecta, seguidas de una investigación de sus propiedades halocromáticas. Los potenciales antibacterianos de los extractos se probaron en importantes patógenos del arroz: Xanthomonas oryzae pv. oryzae, Pantoea agglomeran que son bacterias gram-negativas y en Bacillus subtilis una bacteria gram-positiva. Resultados: Los extractos crudos de T. erecta y A. blanchetii tienen buenas propiedades halocrómicas dentro del pH 2 - 12, mostrando colores distintos. Los cromóforos de C. thevetia, E. crassipes y l. casei no son halocrómicos ya que los colores de los extractos crudos permanecen iguales en el rango de $\mathrm{pH}$, excepto el $\mathrm{pH} 12$, que es similar para los cinco extractos. Los extractos crudos de T. erecta inhibieron el crecimiento de $P$. agglomerans sin desarrollo de resistencia, mientras que las bacterias desarrollaron resistencia contra la penicilina después de 18 horas de incubación. T. erecta y A. blanchetii pudieron inhibir el crecimiento de $X$. oryzae y ambos inhibieron $B$. subtilis. Conclusión: los pigmentos de T. erecta y A. blanchetii son buenos como indicadores de $\mathrm{pH}$. Sin embargo, $T$. erecta es un mejor agente antibacteriano que $A$. blanchetii ya que tiene actividades de amplio espectro contra las bacterias.

Palabras clave: antimicrobiano, halocrómico, Thunbergia erecta, antocianina, Xanthomonas oryzae pv. Oryzae, Pantoea agglomerans, Bacillus subtilis. 
The colours offlowers are a result of pigments produced by plants, which are secondary metabolites. These metabolites have auxiliary functions other than for metabolism and growth of plants (Neilson, Goodger, Woodrow, \& Møller, 2013). The synthesis of secondary metabolites by plants has been attributed to survival mechanisms (Akula \& Ravishankar, 2011). These metabolites have been shown to address specific needs in the evolution of plants (Pichersky \& Gang, 2000; Michael Wink, 2003) and because of the uniqueness of the synthesis of these secondary metabolites in each plant, they are useful as taxonomic markers (Wink \& Mohamed, 2003). Furthermore, the age-long chemical warfare between plants and their pests has necessitated the production of these metabolites some of which serve as toxic substances in defense against pathogens and herbivores, and others to aid territory colonization by inhibiting growth of other plants (Wink, 1988). Conversely, some are colourful with aroma and sweetness to attract animals for seed dispersal (Koes, Verweij, \& Quattrocchio, 2005).

These plants' secondary metabolites have been used as raw materials for the production of medicines since prehistory (Cowan, 1999). Particularly useful as antimicrobial agents that have saved many lives. Since 1928 when Alexander Fleming discovered penicillin from mould, antibiotics production has relied heavily on bacterial and fungal sources, with plant sources virtually ignored (Cowan, 1999). In the past few decades however, there has been a rise in number of antimicrobial resistance (AMR) cases reported worldwide (Blair, Webber, Baylay, Ogbolu, \& Piddock, 2015) against these antibiotics. The most significant case of antibiotics resistance reported is that to the antibiotics of last resort, colistin (Gao et al., 2016). For this reason, developing new antimicrobial agents is important to stem the growing trend of superbugs spreading across the globe. Promising among the sources of antimicrobial agents is therefore the secondary metabolites from plants (Cowan, 1999). The pigmentation of the secondary metabolites of plants also has usefulness in the textile industry, and those that are halochromic (i.e. change color according to $\mathrm{pH}$ changes) are used in colour display and $\mathrm{pH}$ indicators (Forster, 1978; Sharifabad \& Bahrami, 2016).

In this study, in order to explore the halochromic properties and the antimicrobial potentials of the crude extracts of several ornamental plants, we examined both in flowering plants in the gardens around International Institute of Tropical Agriculture, Benin Republic. The characteristic shape of the petals of the flowers were used to identify the selected flowers. Crude extracts from the petals were tested against common pathogens of rice and the halochromic properties of each flower established.

\section{MATERIALS \& METHODS}

Sample collection: the flower samples used in this experiment were collected from the garden at International Institute of Tropical Agriculture (IITA), Cotonou, Benin. The bacteria pathogens were provided and earlier characterized by the Pathology Unit of Africa Rice, Cotonou (Lee, Hong, \& Kim, 2010; Afolabi et al., 2016; Kini et al., 2017).

Identification of flowers: The characteristic shape of leaf, number of petals and colour were used to identify the flowers by comparing them with images of documented flowers.

Extraction of pigments from flower petals: Pigments were extracted from the petals of all the flowers except in E. crassipes, where the thick, glossy leaves were used. Pigments were extracted by crushing $1 \mathrm{~g}$ of petals in $1 \mathrm{~mL}$ of solvent with the use of a mortar and pestle. The slurry generated were transferred into 1,5mL Eppendorf tubes and vortexed (Fisher Vortex Genie 2TM- from Fisher Scientific) for 10 mins for maximum extraction of the pigments. The resultant mixtures were then centrifuged (Eppendorf Centrifuge Model no 5415D) at 11 000RPM for 30mins to recover the solvents, with the supernatant collected into fresh Eppendorf tubes using a micropipette and stored at $4^{\circ} \mathrm{C}$.

Investigating the halochromic properties of the flower extracts: In order to establish the halochromic properties of the extracts from the flowers, aqueous solutions with $\mathrm{pH}$ ranging from 2-12 were prepared by titrating sodium hydroxide with hydrochloric acid. $\mathrm{pH}$ of the titrations was monitored with a pH meter and titration stopped at each desired $\mathrm{pH}$ points. Transparent 96-well plates were used as colour plates. Seven wells for the $\mathrm{pH}$ range and five columns for the different flowers were used. Each well contained $20 \mu \mathrm{L}$ of flower extract, with $20 \mu \mathrm{L}$ of each of the $\mathrm{pH}$ range solutions added to the wells on a row. Colour change of the extracts in each well was observed and recorded.

Antimicrobial screening: This screening was carried out in order to investigate the antibacterial property and rate of bacteria inhibition of the crude extracts of the flowers using two techniques respectively: Agar well diffusion method and growth inhibition in liquid culture, Luria Broth (LB). 
Agar Well Diffusion Method: Lysogeny broth solidified with agar was prepared using, $2 \mathrm{~g}$ of peptone (BactoTM Peptone), $2 \mathrm{~g}$ of $\mathrm{NaCl}$ (Sodium Chloride Certified ACS Crystalline from Fisher Scientific), $1 \mathrm{~g}$ of yeast extract (BactoTM Yeast Extract from Becton Dickinson microbiology systems) and $3 \mathrm{~g}$ of agar (DifcoTMAgar, granulated solidifying agent from Becton Dickinson microbiology systems) in $200 \mathrm{~mL}$ distilled water and then autoclaved (Napco ${ }^{\circledR}$ Model $8000-D S E$ Autoclave). About $20 \mathrm{~mL}$ of the autoclaved nutrient agar was then poured into petri dishes and allowed to solidify. The bacterial samples were applied to the plates using top agar gel. Briefly, 2\% agar was made in distilled water and then autoclaved. Secondary culture of the bacterial samples were inoculated at 1:100 in LB medium and allowed to grow to mid log phase. The $2 \%$ agar solution was allowed to cool down to $40^{\circ} \mathrm{C}$ over water bath and the bacterial growth at mid log phase was quickly added at 1:1 and spread on the nutrient agar plates. A $2 \mathrm{~mm}$ sterile cork borer was used to punch wells $2 \mathrm{~cm}$ apart on the nutrient agar plates. The wells were labelled and filled with $80 \mu \mathrm{L}$ of the crude extracts. Known penicillin concentrations, autoclaved distilled water and acetonitrile were used as positive and negative controls respectively. The plates were then incubated at $37^{\circ} \mathrm{C}$ overnight after the crude extracts have diffused into the plates.

Bacterial growth rate assay: Luria Broth (LB) medium was prepared using $2 \mathrm{~g}$ of peptone, $2 \mathrm{~g}$ of $\mathrm{NaCl}$ and $1 \mathrm{~g}$ of yeast extract in $200 \mathrm{~mL}$ of distilled $\mathrm{H}_{2} \mathrm{O}$. The mixture was split into five aliquots, $500 \mathrm{~mL}$ each in conical flasks to hold $40 \mathrm{~mL}$ of the medium and autoclaved. Secondary culture of the bacterial samples was inoculated at 1:100 in LB medium and allowed to grow to mid log phase. Thereafter, $40 \mu \mathrm{L}$ of penicillin $(100 \mathrm{mg} / \mathrm{mL})$ and $40 \mu \mathrm{L}$ of flower plant extracts (T. erecta) were added to two of the five labelled flasks respectively. Then, $200 \mu \mathrm{l}$ of the bacteria strain was added to the two conical flasks with the antibiotic and flower extract. A third flask was also inoculated as control. The three flasks were mounted on a shaker (Stuart Orbital Shaker SSL1) at $27^{\circ} \mathrm{C}$ and 200RPM. The starting $\mathrm{OD}_{600}$ was recorded and the growth rate monitored at time interval of $30 \mathrm{~min}$ at $\mathrm{OD}_{600}$ using a spectrophotometer (Jenway 6300 Spectrophotometer).

Ethical, conflict of interest and financial statements: the authors declare that they have fully complied with all pertinent ethical and legal requirements, both during the study and in the production of the manuscript; that there are no conflicts of interest of any kind; that all financial sources are fully and clearly stated in the acknowledgements section; and that they fully agree with the final edited version of the article. A signed document has been filed in the journal archives.

\section{RESULTS}

Identification of the flowery plants: The brightly colored petals and leaves of the flowers enabled easy identification when compared with documented flowers. The Fig. 1 shows the images of the flowers collected at IITA Benin's garden and their corresponding names based on the physical characteristic of the leaves and petals.

Extraction of the pigments with aqueous and organic solvents: The pigments in the various petals of the selected ornamental plants exhibited different solubility in water, methanol and acetonitrile. For each flower, the most compatible solvent on the basis of level of solubility and retention of original colour, was selected as shown in Table 1.

Halochromic properties of the crude extracts in $\mathrm{pH}$ range of 2-12: the halochromic properties of the various crude extracts from the flowers were examined at $\mathrm{pH}$ range of $2-2$. The Fig. 2 shows that $T$. erecta and $A$. blanchetii extracts have distinct halochromic properties.

Top agar diffusion screening of the antimicrobial activity of the extracts on Gram-negative bacterium, Pantoea agglomerans: the antibacterial activities of the

TABLE 1

Solvents used for active component extraction

\begin{tabular}{cccc} 
Sample & Flower name & Colour of petal & Extraction solvent \\
$A$ & Thumbergia erecta & Purple & Water \\
$B$ & Allamanda blanchetii & Light pink & Acetonitrile \\
$C$ & Ixora casei & Red & Water \\
$D$ & Cascabela Thevetia & Yellow & Acetonitrile \\
$E$ & Eichornia crassipes & Green leaf & Methanol \\
\hline
\end{tabular}




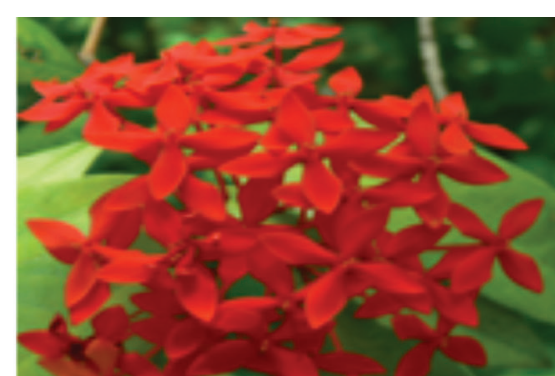

Ixora casei

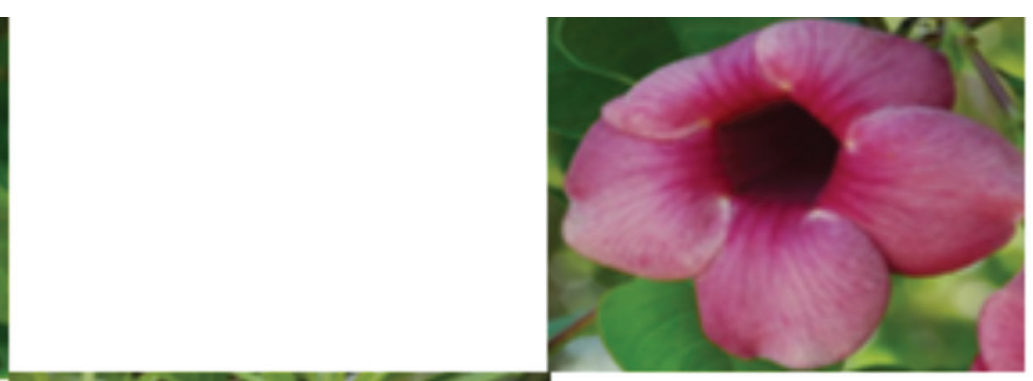

Allamanda blanchetii

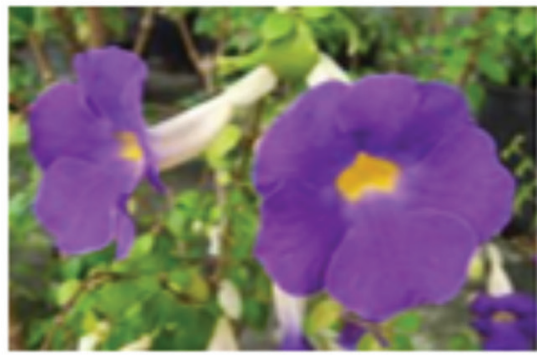

Thumbergia erecta

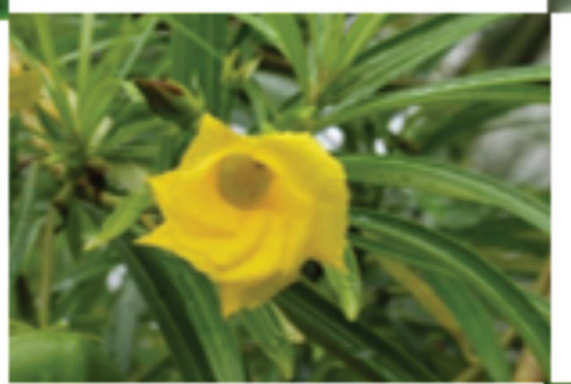

Cascabela thevetia

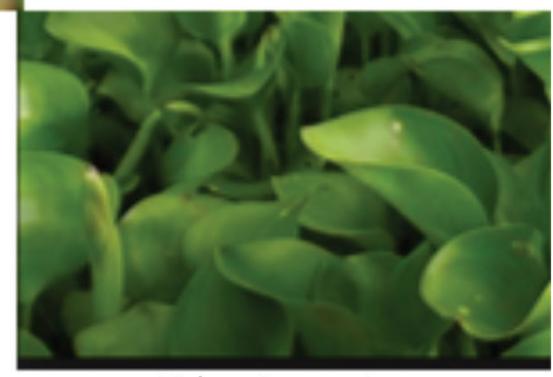

Eichornia crassipes

Fig. 1. Flowers used for the halochromic and antimicrobial screening: Ixora Casei (Rubiaceae), Allamanda blanchetii (Apocynaceae), Cascabela Thevetia (Apocynaceae), Thumbergia erecta (Acanthaceae), Eichornia crassipes (Pontederiaceae).

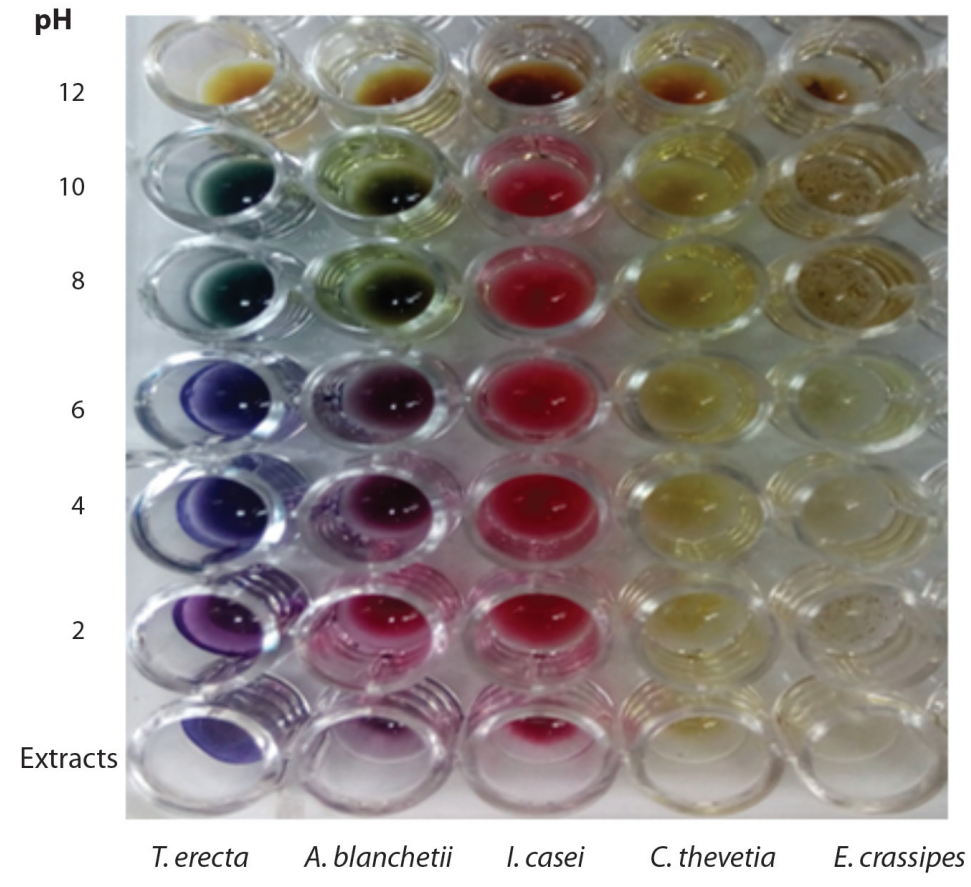

Fig. 2. Halochromic properties of the various flower extracts: Two of the extracts (T. erecta and A. banchetti) show different colours at the various $\mathrm{pH}$ range examined. 
extracts were examined on $P$. agglomerans and a purified crystalline penicillin at three concentrations of $200 \mathrm{mg} /$ $\mathrm{mL}, 100 \mathrm{mg} / \mathrm{mL}$ and $50 \mathrm{mg} / \mathrm{mL}$ were used as positive control while sterile distilled water was used as negative control. The Fig. 3 shows the top agar plates of the incubation and bacterial growth inhibitions by the extracts and controls observed at 6hrs and 18hrs. Out of all the crude extracts only $T$. erecta shows antibacterial activities against

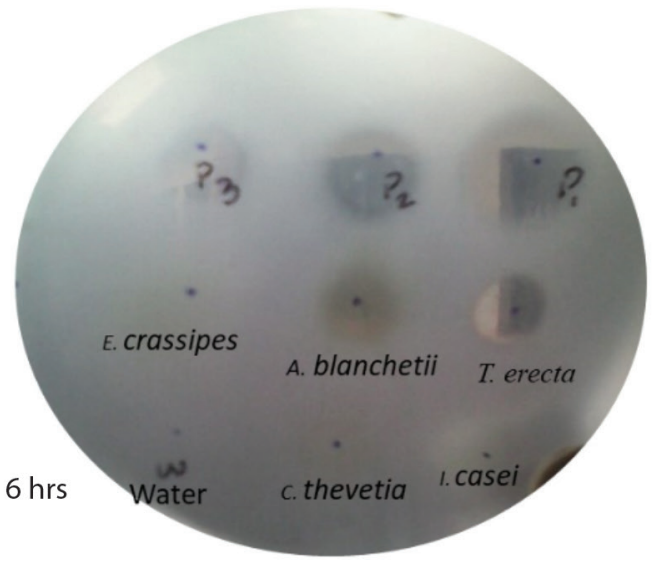

the $P$. agglomerans. Penicillin also inhibited the growth of the gram-negative bacterium as shown in Fig. 3.

We, however, observed resistance being developed by the bacterium after $18 \mathrm{hrs}$ of incubation and a noticeable resistance ring forming against penicillin. Fig. 3b shows the various ring formations and the inhibition rings represented as Bar Chat in Fig. 4. The highest concentration of penicillin inhibited the growth of the bacterium to

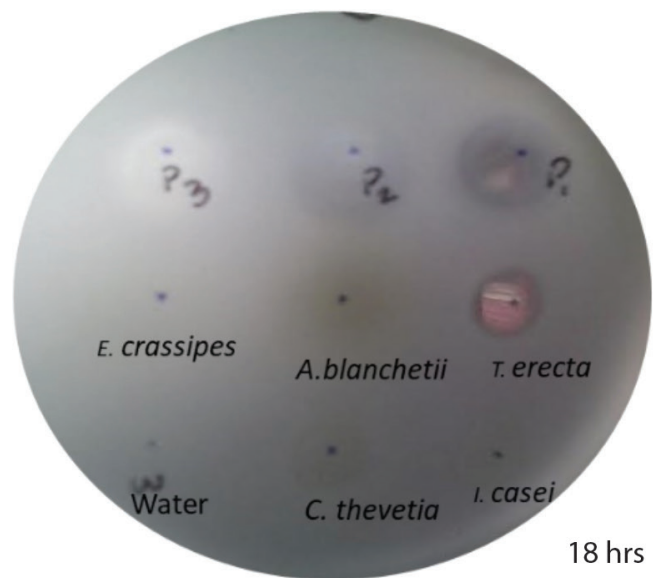

Fig. 3A \& B. Top agar diffusion experiment of the antimicrobial activities of the crude extracts on P. agglomerans. Concentrations of the penicillin used were $200 \mathrm{mg} / \mathrm{mL}, 100 \mathrm{mg} / \mathrm{mL}$ and $50 \mathrm{mg} / \mathrm{mL}$ represented as P1 - P3 respectively on the plates.

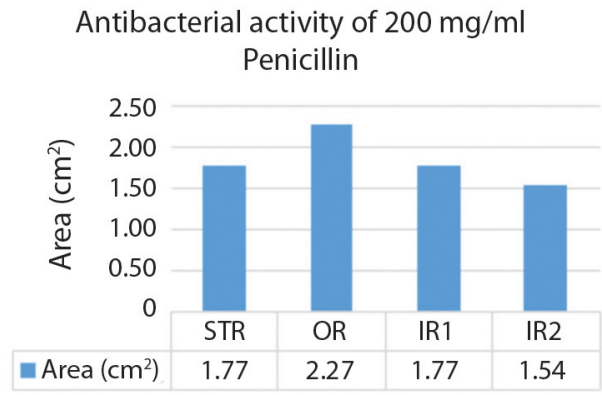

Antibacterial activity of $50 \mathrm{mg} / \mathrm{ml}$ Penicillin

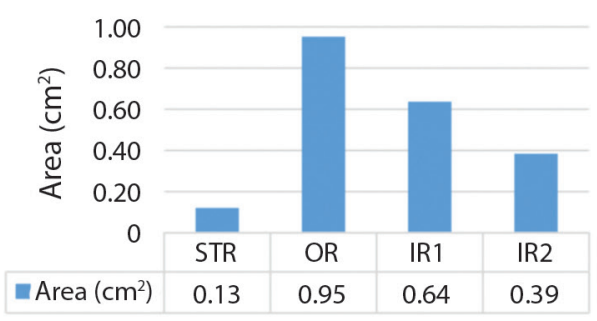

Antibacterial activity of $100 \mathrm{mg} / \mathrm{ml}$ Penicillin

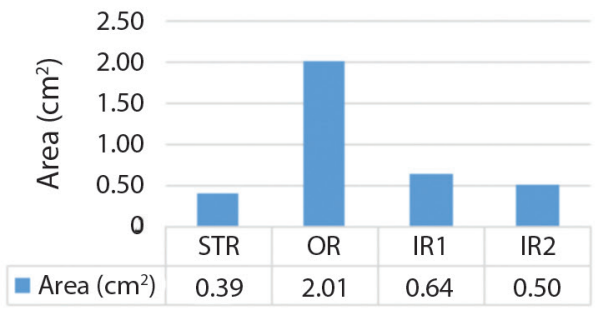

Antibacterial activity of $20 \mu \mathrm{g}$ of T. erecta crude extract

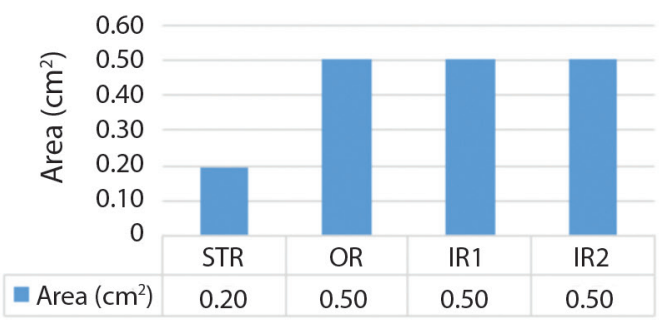

Fig. 4. The $24 \mathrm{hr}$ incubation with the antimicrobial agents comparing growth rate and resistance of the bacteria over time. The diameters of the inhibitions were taken, and the area of inhibition plotted as Bar-Chats. It was observed that the bacteria quickly developed resistance to penicillin as indicated by various rings seen on the plate: STR- Start (6hrs incubation; OR- outer ring; IR1 $1^{\text {st }}$ inner ring; IR2- $2^{\text {nd }}$ inner ring). 


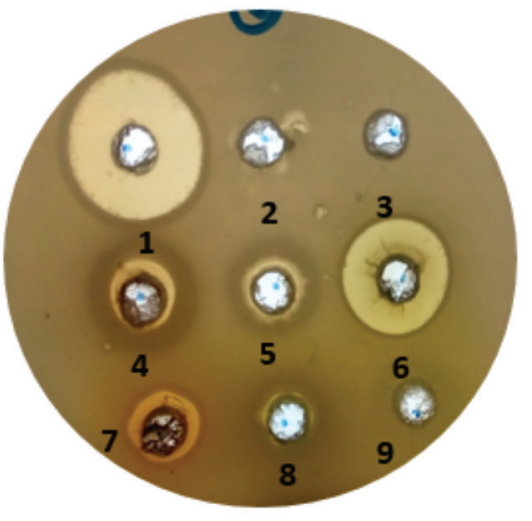

B. subtilis

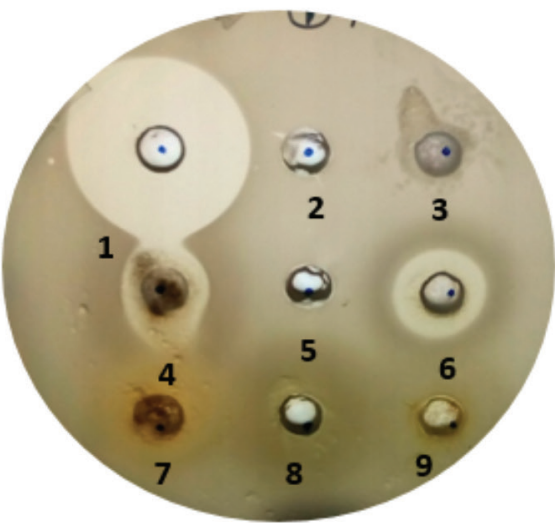

X. oryzae

Fig. 5. Top agar diffusion experiment of the antimicrobial activities of the crude extracts on B. subtilis and $X$. oryzae.1- Peniclline (200 $\mathrm{mg} / \mathrm{mL}$ ), 2- ethanol, 3-phosphate buffer, 4- A. blanchetii,, 5- I. casei 6- T. erecta, 7-Propolis, 8- E. crassipes, 9- C. Thevetia

Antibacterial activities of the crude extracts of the flowers

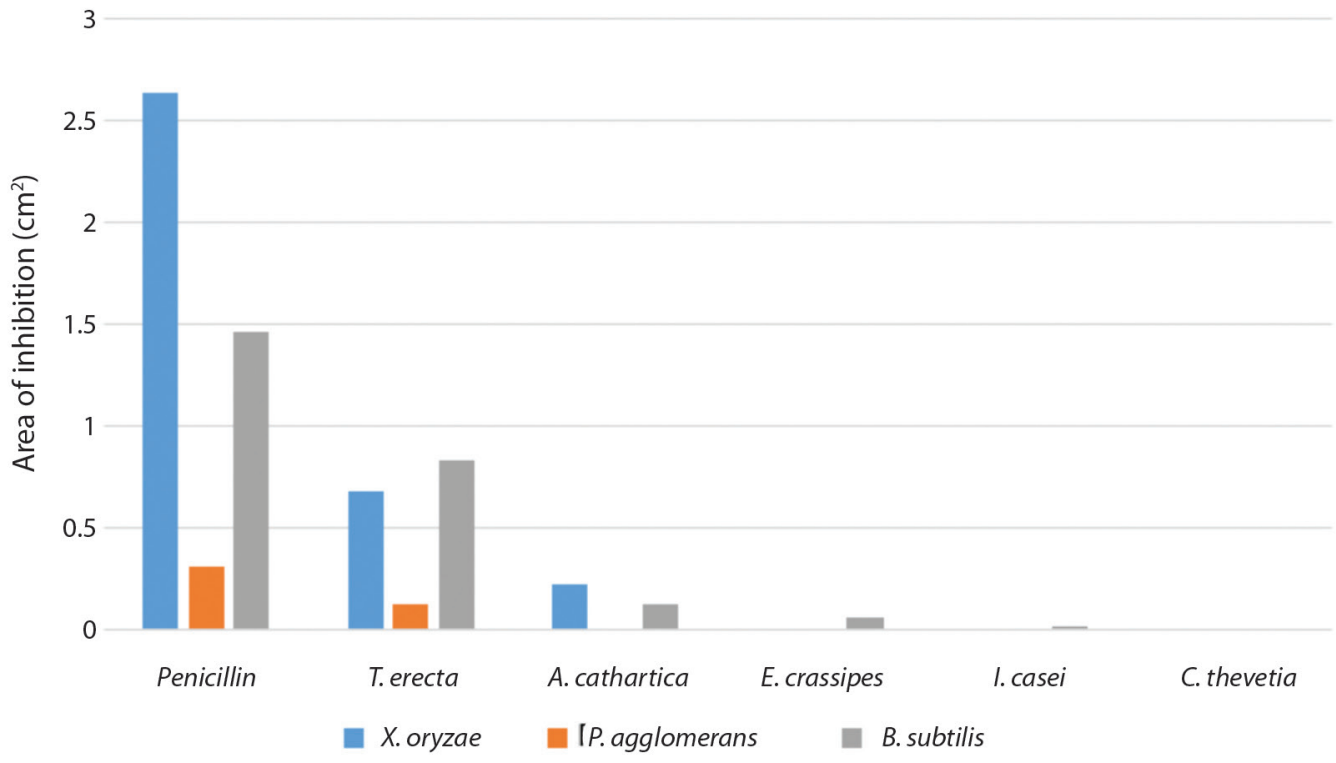

Fig. 6. Summarised data of the top agar diffusion experiments of the antimicrobial activities of the extracts against the three bacteria used. Purified known concentration $(200 \mathrm{mg} / \mathrm{mL})$ of penicillin used as control.

$2,27 \mathrm{~cm}^{2}$ in $24 \mathrm{hrs}$ but the bacterium resisted by reducing the inhibition to $1,77 \mathrm{~cm}^{2}$ forming the first inner ring and then to $1,54 \mathrm{~cm}^{2}$ forming the second inner ring. No resistance rings were formed with the growth inhibition by T. erecta.

Comparison of the extracts on gram-positive Bascillus subtilis and gram-negative bacterium Xanthomonas oryzae pv. oryzae using top agar diffusion: all the extracts have some levels of inhibition against the gram-positive bacterium except $C$. thevetia.
However, only T. erecta and A. blanchetii have antimicrobial activities against $X$. oryzea as shown in Fig. 5 .

We further examined the ability of the T. erecta in bacterial inhibition growth in LB medium culture comparing it with penicillin.

\section{DISCUSSION}

Halochromic properties of the crude extracts: purple pigmentation in flowers are associated with the 

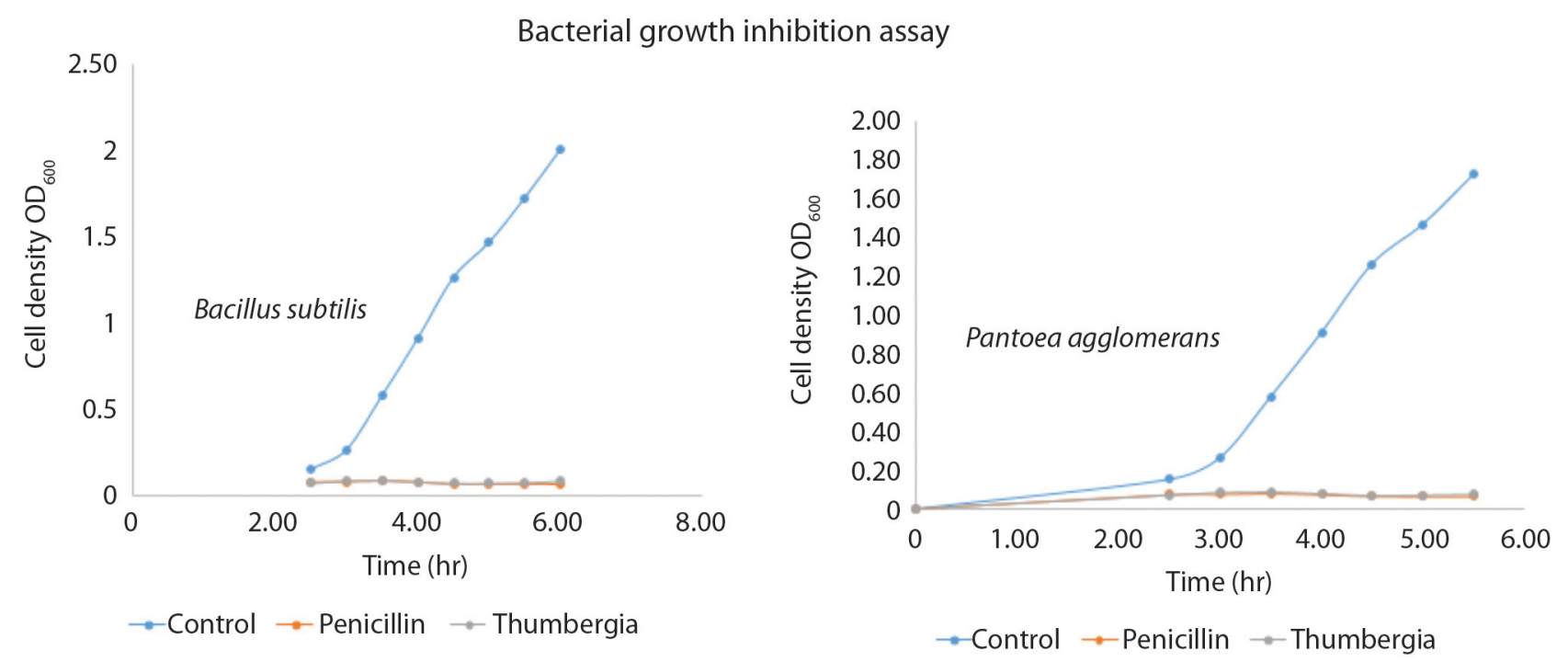

Fig. 7. (A) Bacterial growth monitored at $\mathrm{OD}_{600}$ in the presence of $200 \mu \mathrm{g} / \mathrm{mL}$ of penicillin and $180 \mu \mathrm{L}$ of T. erecta. Penicillin and T. erecta extract were added into $40 \mathrm{~mL} \mathrm{LB}$ and a primary culture of both $B$. subtilis and $P$. agglomerans grown to $0.5 \mathrm{OD}_{600}$ was inoculated into the LB. T. erecta extract was first incubated 1:1 $(200 \mu \mathrm{L})$ with the bacterium of $\mathrm{OD}_{600} 0.5$ for $1 \mathrm{hr}$ before starting the secondary culture in $40 \mathrm{~mL}$ LB. Control was treated same way but with deionised water. This was done to increase rate of interaction of the extract with the bacterium because of its low concentration.

synthesis of anthocyanins by plants (Archetti et al., 2009). Anthocyanins are a subclass of phenolic phytochemicals in the forms of anthocyanidin glycosides and acylated anthocyanins (Khoo et al., 2017). These are water soluble secondary metabolites (Geissman, 1955; Khoo et al., 2017) and their colour depend on the $\mathrm{pH}$ of the solution because of the ionic charge of their molecular structure (Turturica, Oancea ,Râpeanu, \& Bahrim, 2015). They have been found in all the tissues of higher plants and are derivatives of anthocyanidins (Andersen \& Jordheim, 2010). Halochromic property of anthocyanidins have been proposed to be a good pH indicator (Michaelis, Schubert, \& Smythe, 1936) and antimicrobial activities established in berries (Miceli et al., 2009; Genskowsky et al., 2016). The halochromic property of anthocyanin extracted from raspberry juice is being used as colour indicator to monitor the $\mathrm{pH}$ change of wound which depends on healing stages and presence of infection (Coomber, 2018). The exhibition of halochromic property observed in T. erecta and $A$. banchetti indicated they have pigments with ionic molecular structure. Further work will be required to confirm the identity of these charged pigments.

Antimicrobial activity: Thunbergia erecta is one of the common species of Thunbergia (Sultana, Chatterjee, Roy, \& Chandra, 2015). Members of these species have been found to have antimicrobial activities against both gram positive and gram negative bacteria (Jeeva, Johnson, Aparna, \& Irudayaraj, 2011; Jenifer, et al., 2014; Kosai, Jiraungkoorskul, \& Jiraungkoorskul, 2015). The anti-microbial activities of $T$. erecta against Panteoa agglomeran and Xanthomonas oryzae are remarkable. Pantoea agglomerans and Xanthomonas oryzae pv. ory$z a e$ are both pathogens of rice cultivation (Salzberg et al., 2008; Lang et al., 2010; Lee et al., 2010) . They are rodshaped, gram-negative bacteria found in both temperate and tropical parts of the world and cause $10-50 \%$ yield losses. Recently, Pantoea agglomerans were discovered to be the plight of farmers on wild rice Oryza longistaminata plants near Tanguiéta town, at Pendjari National Park, northwest Benin republic (Afolabi et al., 2016; Kini et al., 2017).

The mode of action of antimicrobial agents are classified into six: cell wall synthesis inhibition, protein synthesis inhibition, DNA synthesis inhibition, RNA synthesis inhibition, mycolic acid synthesis inhibition and folic acid inhibition (Hugo, 1967; Hahn, 2012). Penicillin is a cell wall inhibitor (Wise \& Park, 1965). Antimicrobial resistance of bacteria to penicillin is the production of enzymes capable of destroying the b-lactam ring of penicillin (Tenover, 2006). Once the penicillin is destroyed, resistance ring will form signifying clearance of the antibiotics and demonstrating the resistance status of the bacteria. The additional outer membrane layer of gram-negative organisms differentiates them from gram-positive organisms. This provides additional protection and thereby enhancing survival during stress conditions (Schwechheimer \& Kuehn, 2015). The Fig. 3 and 5 show the gram-negative $P$. agglomerans and $X$. 
oryzae respectively resisting some of the flower extracts while the gram-positive, $B$. subtilis, was susceptible to all the extracts except $C$. thevetia.

Based on the results obtained from this research, it can be concluded that the secondary metabolites from the crude extract of T.erecta is a promising antimicrobial candidate whose bioactive component can be exploited to aid in the fight against the rising problem of antimicrobial resistance. The absence of resistance ring by bacteria against $T$. erecta shows that the mode of action of this antimicrobial agent is different from that of penicillin. Isolation, purification and identification of the pigments from the crude extract of T.erecta would give better understanding of the active pigment responsible for these useful properties and add to the arsenal of molecules to fight antimicrobial resistance.

\section{ACKNOWLEDGEMENTS}

The authors wish to acknowledge Rousseau Djouaka, AgroEcoHealth IITA and his team for allowing us to use his facilities at IITA Benin Republic for this experiment. We also acknowledge other members of the Pathology unit of AfricaRice for their contributions.

\section{REFERENCES}

Afolabi, O., Amoussa, R., Bilé, M., Oludare, A., Gbogbo, V., Poulin, L., ... Silué, D. (2016). First report of bacterial leaf blight of rice caused by Xanthomonas oryzae pv. oryzae in Benin. Plant Disease, 100(2), 515-515. DOI:10.1094/ PDIS-07-15-0821-PDN

Akula, R., \& Ravishankar, G. A. (2011). Influence of abiotic stress signals on secondary metabolites in plants. Plant signaling \& behavior, 6(11), 1720-1731. DOI:10.4161/ psb.6.11.17613

Andersen, Ø. M., \& Jordheim, M. (2010). Anthocyanins. eLS. Chichester: JohnWiley \& Sons DOI:10.1002/9780470015902.a0001909.pub2

Archetti, M., Döring, T. F., Hagen, S. B., Hughes, N. M., Leather, S. R., Lee, D. W., . . S Schaberg, P. G. (2009). Unravelling the evolution of autumn colours: an interdisciplinary approach. Trends in ecology \& evolution, 24(3), 166-173. DOI:10.1016/j.tree.2008.10.006

Blair, J. M., Webber, M. A., Baylay, A. J., Ogbolu, D. O., \& Piddock, L. J. (2015). Molecular mechanisms of antibiotic resistance. Nature Reviews Microbiology, 13(1), 42. DOI:10.1038/ nrmicro3380

Coomber, A. (2018). Wound dressing materials incorporating anthocyanins derived from fruit or vegetable sources: US
Patent App. 15/830, 188. Washington, DC: U.S. Patent and Trademark Office.

Cowan, M. M. (1999). Plant products as antimicrobial agents. Clinical microbiology reviews, 12(4), 564-582. DOI:10.1128/CMR.12.4.564

Forster, M. (1978). Plant pigments as acid-base indicators-An exercise for the junior high school. Journal of Chemical Education, 55(2), 107. DOI:10.1021/ed055p107

Gao, R., Hu, Y., Li, Z., Sun, J., Wang, Q., Lin, J., .. . Li, D. (2016). Dissemination and mechanism for the MCR-1 Colistin resistance. PLoS pathogens, 12(11), e1005957. DOI:10.1371/journal.ppat.1005957

Geissman, T. (1955). Anthocyanins, chalcones, aurones, flavones and related water-soluble plant pigments Moderne Methoden der Pflanzenanalyse/Modern Methods of Plant Analysis (pp. 450-498): Springer. DOI:10.1007/978-3-642-64958-5_12

Genskowsky, E., Puente, L. A., Pérez®Álvarez, J. A., Fernándezญ López, J., Muñoz, L. A., \& Viuda冈Martos, M. (2016). Determination of polyphenolic profile, antioxidant activity and antibacterial properties of maqui [Aristotelia chilensi s (Molina) Stuntz] a Chilean blackberry. Journal of the Science of Food and Agriculture, 96(12), 4235-4242. DOI:10.1002/jsfa.7628

Hahn, F. E. (2012). Mechanism of action of antibacterial agents. Berlin, Germany: Springer Science \& Business Media.

Hugo, W. (1967). The mode of action of antibacterial agents. Journal of Applied Microbiology, 30(1), 17-50.

Jeeva, S., Johnson, M., Aparna, J., \& Irudayaraj, V. (2011). Preliminary phytochemical and antibacterial studies on flowers of selected medicinal plants. International Journal of Medicinal and Aromatic Plants, 1(2), 107-114.

Jenifer, S., Priya, S., Laveena, D. K., Singh, S. J. S., \& Jeyasree, J. (2014). Sensitivity patterns of some flowering plants against Salmonella typhi and Pseudomonas aeruginosa. Journal of Pharmaceutical Sciences, 3, 1212-1220.

Khoo, H. E., Azlan, A., Tang, S. T., \& Lim, S. M. (2017). Anthocyanidins and anthocyanins: colored pigments as food, pharmaceutical ingredients, and the potential health benefits. Food \& nutrition research, 61(1), 1361779. DOli:10.1080/16546628.2017.1361779

Kini, K., Agnimonhan, R., Afolabi, O., Milan, B., Soglonou, B., Gbogbo, V., ... Silué, D. (2017). First report of a new bacterial leaf blight of rice caused by Pantoea ananatis and Pantoea stewartii in Benin. Plant Disease, 101(1), 242242. DOI:10.1094/PDIS-06-16-0939-PDN

Koes, R., Verweij, W., \& Quattrocchio, F. (2005). Flavonoids: a colorful model for the regulation and evolution of biochemical pathways. Trends in plant science, 10(5), 236-242. DOI:10.1016/j.tplants.2005.03.002

Kosai, P., Jiraungkoorskul, K., \& Jiraungkoorskul, W. (2015). Review of antidiabetic activity of "Rang Jeud" 
Thunbergia laurifolia. Journal of Applied Pharmaceutical Science, 5, 99-103.

Lang, J. M., Hamilton, J. P., Diaz, M. G. Q., Van Sluys, M. A., Burgos, M. R. G., Vera Cruz, C. M., ... Leach, J. E. (2010). Genomics-based diagnostic marker development for Xanthomonas oryzae pv. oryzae and X. oryzae pv. oryzicola. Plant Disease, 94(3), 311-319. DOI:10.1094/ PDIS-94-3-0311

Lee, H., Hong, J., \& Kim, S. (2010). First report of leaf blight caused by Pantoea agglomerans on rice in Korea. Plant Disease, 94(11), 1372-1372. DOI:10.1094/PDIS-05-10-0374

Miceli, N., Trovato, A., Dugo, P., Cacciola, F., Donato, P., Marino, A., ... Taviano, M. F. (2009). Comparative analysis of flavonoid profile, antioxidant and antimicrobial activity of the berries of Juniperus communis L. var. communis and Juniperus communis L. var. saxatilis Pall. from Turkey. Journal of Agricultural and Food Chemistry, 57(15), 65706577. DOI:10.1021/jf9012295

Michaelis, L., Schubert, M. P., \& Smythe, C. (1936). Potentiometric study of the flavins. Journal of Biological Chemistry, 116, 587-607.

Neilson, E. H., Goodger, J. Q., Woodrow, I. E., \& Møller, B. L. (2013). Plant chemical defense: at what cost? Trends in plant science, 18(5), 250-258. DOI:10.1016/j. tplants.2013.01.001

Pichersky, E., \& Gang, D. R. (2000). Genetics and biochemistry of secondary metabolites in plants: an evolutionary perspective. Trends in plant science, 5(10), 439-445. DOI:10.1016/S1360-1385(00)01741-6

Salzberg, S. L., Sommer, D. D., Schatz, M. C., Phillippy, A. M., Rabinowicz, P. D., Tsuge, S., ... Kelley, D. (2008). Genome sequence and rapid evolution of the rice pathogen Xanthomonas oryzae pv. oryzae PXO99 A. BMC genomics, 9(1), 204. DOI:10.1186/1471-2164-9-204

Schwechheimer, C., \& Kuehn, M. J. (2015). Outer-membrane vesicles from Gram-negative bacteria: biogenesis and functions. Nature Reviews Microbiology, 13(10), 605. DOI:10.1038/nrmicro3525

Sharifabad, A. N., \& Bahrami, S. H. (2016). Halochromic Chemosensor From Poly (acrylonitrile)/Phenolphthalein Nanofibers as pH Sensor. IEEE Sensors Journal, 16(4), 873880. DOI:10.1109/JSEN.2015.2495338

Sultana, K., Chatterjee, S., Roy, A., \& Chandra, I. (2015). An Overview on Ethnopharmacological and Phytochemical properties of Thunbergia sp. Med Aromat Plants, 4(217), 2167-0412.100021.

Tenover, F. C. (2006). Mechanisms of antimicrobial resistance in bacteria. American journal of infection control, 34(5), S3S10. DOI:10.1016/j.ajic.2006.05.219

Tuturica, M., Oancea, A., Râpeanu, G., \& Bahrim, G. (2015). Anthocyanins: naturally occuring fruit pigments with functional properties. Annals of the University Dunarea de Jos of Galati Fascicle VI--Food Technology, 39(1), 9-24,

Wink, M. (1988). Plant breeding: importance of plant secondary metabolites for protection against pathogens and herbivores. Theoretical and applied genetics, 75(2), 225-233. DOI:10.1007/BF00303957

Wink, M. (2003). Evolution of secondary metabolites from an ecological and molecular phylogenetic perspective. Phytochemistry, 64(1), 3-19. DOI:10.1016/ S0031-9422(03)00300-5

Wink, M., \& Mohamed, G. I. (2003). Evolution of chemical defense traits in the Leguminosae: mapping of distribution patterns of secondary metabolites on a molecular phylogeny inferred from nucleotide sequences of the rbcL gene. Biochemical Systematics and Ecology, 31(8), 897-917. DOI:10.1016/S0305-1978(03)00085-1

Wise, E. M., \& Park, J. T. (1965). Penicillin: its basic site of action as an inhibitor of a peptide cross-linking reaction in cell wall mucopeptide synthesis. Proceedings of the National Academy of Sciences, 54(1), 75-81. DOI:10.1073/ pnas.54.1.75 